\title{
https://doi.org/10.48009/2_iis_2006_202-207 \\ CONSUMERS' ATTITUDES OF E-COMMERCE IN CHINA
}

\author{
Xiaowen Zou, University of Shanghai for Science and Technology, sky2002336@ hotmail.com \\ Hengshan Wang, University of Shanghai for Science and Technology, wanghengshan@yahoo.com \\ Hongjiang Xu, Central Michigan University, xu1h@cmich.edu
}

\begin{abstract}
This research studied the problem of $B 2 C$ and $C 2 C$ consumers' attitudes towards trust of the business transaction process in China by using the "Consumer Attitudes towards Trust in the $e$ Business Model." Four factors in the model were analyzed, privacy, security, financial institution and trusted seal. From this analysis, the conclusion on the consumers' attitudes was drawn.
\end{abstract}

Keywords: E-commerce, Trust, Privacy, Security

\section{INTRODUCTION}

While the digital economy has a promising future, two related issues, privacy and security, may prove to be a formidable barrier to its growth. Cahner's In-Stat Research study points out that e-commerce companies consider trust to be the most important issue. There are two things that can slow down the e-commerce growth surge: a loss of trust among customers about the protection of their privacy and the security of transaction systems. However, trust is not easy to measure. It is developed over time.

Since business to consumer (B2C) and consumer to consumer (C2C) E-commerce began to develop more and more quickly over the last few years, consumers can shop around the clock from merchants around the world [15]. Due to this growth, more attention must be paid to the trust in business transaction processes, for it will affect consumers' consumption. $\mathrm{B} 2 \mathrm{C}$ and $\mathrm{C} 2 \mathrm{C}$ are comparatively new things in China; therefore, Chinese consumers' attitudes towards trust in ecommerce transaction process are interesting and worth research. This study reveals the Chinese consumers' current concerns of privacy and security in e-commerce. The results of the research could help the B2C and $\mathrm{C} 2 \mathrm{C}$ companies in China gain a better understanding of the consumers' trust and further improve their e-commerce transaction environment to obtain more trust from the Chinese consumers.

\section{Research Problem}

The research is intended to analyze $\mathrm{B} 2 \mathrm{C}$ and $\mathrm{C} 2 \mathrm{C}$ consumers' attitudes towards trust of the business transaction processes in China which could be divided into two sub-problems: 1) Analyze the primary data of $\mathrm{B} 2 \mathrm{C}$ and $\mathrm{C} 2 \mathrm{C}$ consumers' attitudes towards the trust of the business transaction process in China by using four aspects in the "Consumer Attitudes towards Trust in the e-Business Model," 2) Analyze and interpret the treated data so as to evaluate the differences in $\mathrm{B} 2 \mathrm{C}$ and $\mathrm{C} 2 \mathrm{C}$ consumers' attitudes towards the trust of the business transaction process in China. According to the sub-problems, the hypotheses are:

H1: Consumers in China of different ages and genders with different purchasing power have the same concerns during the on-line transaction process

H2: There is no difference in B2C and C2C consumers' attitudes towards trust of the business transaction process in China

\section{METHODOLOGY}

\section{Theoretical Framework}

As shown in Figure 1, "Consumer Attitudes towards Trust in the e-Business Model," consumers' concern includes four parts: privacy, security, financial institution and trusted seal. Those factors are supposed to have an effect on consumers' attitudes towards trust. This theoretical framework has two parts, Part 1 is based on the privacy-trust component of the "Privacy-trust-behavioral Intention Model of Electronic Commerce," which explain how privacy influence trust [1], and Part 2 is based on the Consumer Trust part of the "Trust Model," which regards security, financial institution and trusted seal as the key components [17]. 


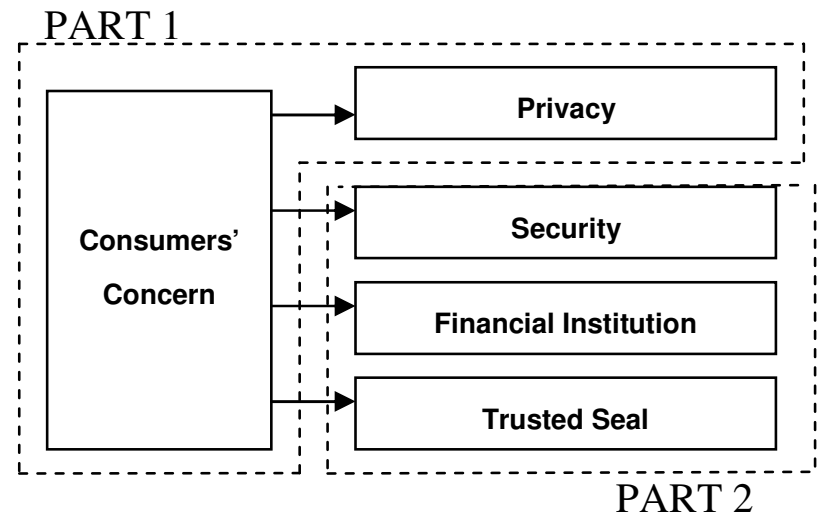

Sources: PART 1 [1] ; PART 2 [17]

Figure 1. Consumer Attitudes towards Trust in the e-Business Model

\section{Development of the Survey Questionnaire}

The survey questionnaire design refers to the research questions of the "Effect of Brand Name on Consumers' Risk Perceptions of Online Shopping" [6], the "Online - Questionnaire Design" [1], the "Graphic, Visualization, \& Usability Center's (GVU) 6th WWW User Survey" [5] and the "Web Assurance Seal"[13].

The survey questionnaire is divided into 3 parts.

1) The single choice questions for collecting general information of the consumers: age, gender and money spent on-line per year.

2) The ratio scale questions from 1 (strongly agree) to 5 (strongly disagree) for collecting the attitude of the four aspects in the "Consumer Attitudes towards the Trust in e-Business Model" of the consumers: privacy, security, financial institution and trusted seal

3) The open-ended questions for collecting the consumers' attitudes towards the differences of $\mathrm{B} 2 \mathrm{C}$ and $\mathrm{C} 2 \mathrm{C}$ transactions.

\section{Data Collection Method}

This research utilizes college students as the survey participants. Liu and $\mathrm{Lu}$ [9] gave a very good explanation for why college students are an acceptable sample for studying e-commerce issues. First, college students are the most active users of new technology. Additionally, because all the students in the sample completed a basic computer course, they have better computer skills.
The questionnaires were distributed and collected in class. Complete and usable questionnaires were received from 75 participants.

\section{Data Analysis}

With the analysis by ANOVA using three categorization variables-age, gender and money spent on-line per year, some interesting results were found.

As shown in Table 1, there is a strong relationship between the consumer's money spent on-line per year and the consideration of the security threat to on-line payment (Q7), companies' effort to ensure the payment security (Q9), and the third-party financial institutions' effort to ensure the payment security (Q13). The more they purchase, the more consumers are concerned with these three questions. It is easy to understand why consumers who are spending lots of money pay most of their attention to the payment concerns other than the privacy concern and the trusted seal concerns. The amount of money makes them neglect the other trivial issues. Two other obvious relationships are found in Table 2 and 3. First, female consumers focus more on the investigation of historical records for transaction security (Q12). The other is that male consumers focus more on the historical records of consumers' personal information protection from the e-business companies (Q5). This kind of result is not too surprising because female consumers are always more cautious with money than male consumers, as most of them handle the financial issues in the Chinese family. Alternatively, male consumers focus more on freedom and privacy.

To reduce the probability of committing a Type I error when multiple comparisons are done is to divide Alpha by the number of tests, and using that number as the new Alpha. The Alpha is originally set at 0.05 , and three tests are being done, so the new Alpha is $0.05 / 3=0.017$. A P value from any of the three comparisons must be less than or equal to 0.0167 to be considered statistically significant.

Furthermore, when the attitudes towards the differences of $\mathrm{B} 2 \mathrm{C}$ and $\mathrm{C} 2 \mathrm{C}$ are taken into account, $51.51 \%$ of the consumers believed that there were some differences between $\mathrm{B} 2 \mathrm{C}$ and $\mathrm{C} 2 \mathrm{C}$. These differences were found in consumers' information/privacy protection, and $85.29 \%$ of those consumers thought the $\mathrm{B} 2 \mathrm{C}$ did a better job than $\mathrm{C} 2 \mathrm{C}$, because the transactions of $\mathrm{B} 2 \mathrm{C}$ mainly 
have larger scales and pay more attention to their reputation. While when considering the on-line payment issue, $55.93 \%$ people believed there was not any difference between B2C and C2C, for most payments were dealt with by third-party financial institutions and people could easily choose online- banks as the safest way. However, among the rest of the $45 \%$ of consumers, $84.62 \%$ of them chose to trust $\mathrm{B} 2 \mathrm{C}$ more than $\mathrm{C} 2 \mathrm{C}$ for the same reason as above.

Table 1. ANOVA for Money Spent On-line Per Year

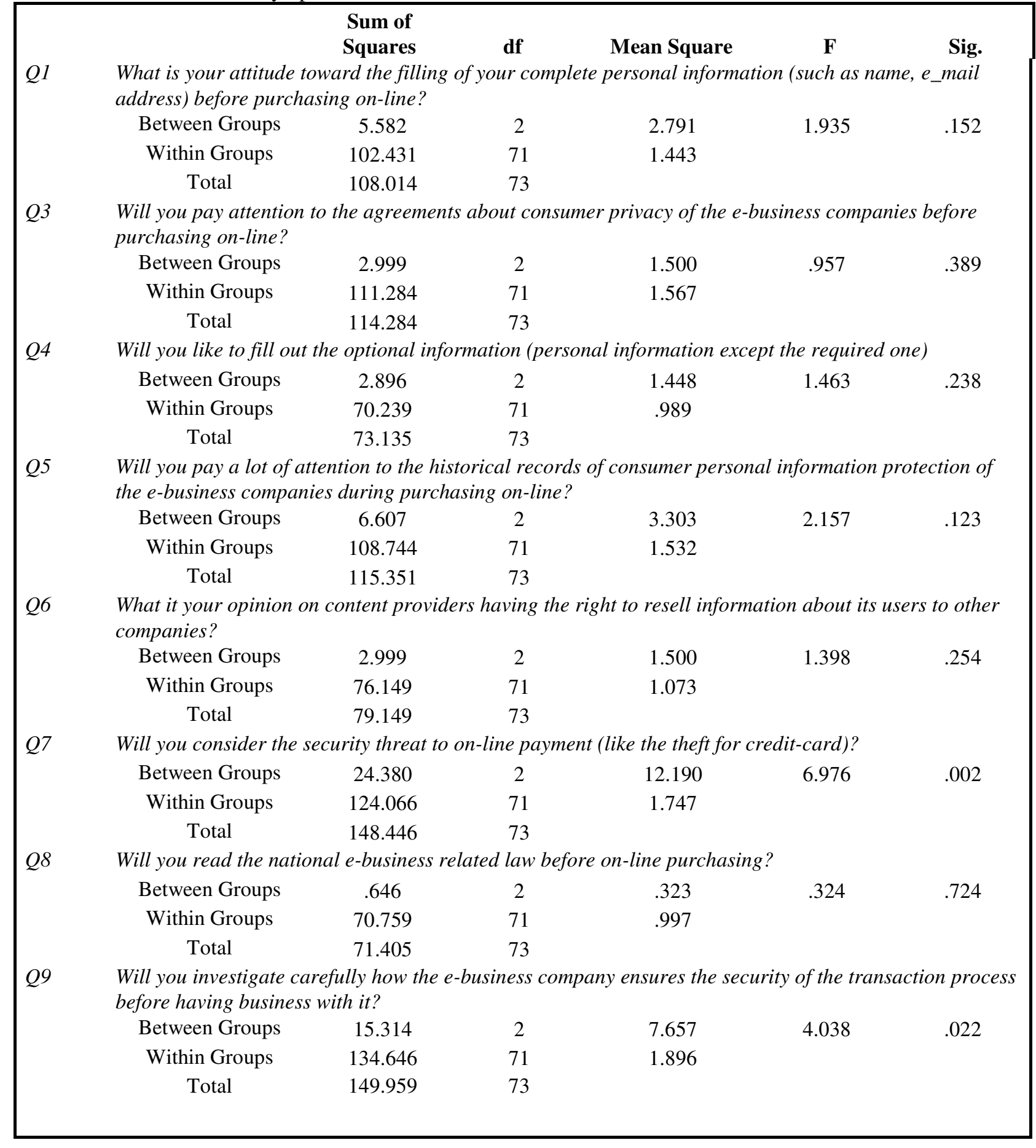




\section{Sum of \\ $\begin{array}{lllll}\text { Squares } & \text { df } & \text { Mean Square } & \text { F } & \text { Sig. }\end{array}$}

Q10 Do you often have the transaction security bother during your on-line purchasing?

$\begin{array}{ccccc}\text { Between Groups } & 5.248 & 2 & 2.624 & 2.456 \\ \text { Within Groups } & 75.847 & 71 & 1.068 & \\ \text { Total } & 81.095 & 73 & \end{array}$

Q11 Will you try to find the concept of some basic concept in e-commerce file such as digital signature and SSL?

$\begin{array}{ccccc}\text { Between Groups } & 8.181 & 2 & 4.090 & 2.253 \\ \text { Within Groups } & 128.914 & 71 & 1.816 & \\ \text { Total } & 137.095 & 73 & & \end{array}$

Will you investigate carefully the historical record for transaction security bother for the e-business company before purchasing on-line?

$\begin{array}{ccccc}\text { Between Groups } & 10.195 & 2 & 5.098 & 2.430 \\ \text { Within Groups } & 148.940 & 71 & 2.098 & \\ \text { Total } & 159.135 & 73 & & \end{array}$

Q13 Will you pay attention to how the third parties, such as the on-line baking which provide on-line payment service, ensure the security of payment?
Between Groups
16.812
2
8.406
5.423
.006
Within Groups
110.053
71
1.550
Total
126.865
73

Q15 Compared with direct payment to the e-business companies, what is your opinion on the third party financial institution?

$\begin{array}{ccccc}\text { Between Groups } & .240 & 2 & .120 & .144 \\ \text { Within Groups } & 58.390 & 70 & .834 & .866 \\ \text { Total } & 58.630 & 72 & & \end{array}$

Q16 I would prefer Internet payment systems that are anonymous to those that are user identified.

\begin{tabular}{|c|c|c|c|c|}
\hline Between Groups & 4.044 & 2 & 2.022 & 1.475 \\
\hline Within Groups & 95.956 & 70 & 1.371 & \\
\hline Total & 100.000 & 72 & & \\
\hline
\end{tabular}

Q17 Will you check the latest network technologies' impact on consumer security before purchasing on-line?

\begin{tabular}{ccccc} 
Between Groups & 4.457 & 2 & 2.228 & 1.698 \\
Within Groups & 91.872 & 70 & 1.312 & \\
Total & 96.329 & 72 & & \\
\hline
\end{tabular}

Table 2. ANOVA for Gender Tendency (questions have sig. values only)

\begin{tabular}{|lc|c|c|c|c|c|}
\hline & $\begin{array}{c}\text { Sum of } \\
\text { Squares }\end{array}$ & df & Mean Square & F & Sig. \\
\hline$Q 5$ & Between Groups & 8.688 & 1 & 8.688 & 5.865 & .017 \\
& Within Groups & 106.663 & 72 & 1.481 & & \\
& Total & 115.351 & 73 & & \\
& Between Groups & 18.559 & 1 & 18.559 & & .003 \\
& Within Groups & 140.576 & 72 & 1.952 & & \\
& Total & 159.135 & 73 & & & \\
\hline
\end{tabular}


Table 3. ANOVA for Age Tendency (questions have sig. values only)

\begin{tabular}{|c|c|c|c|c|c|c|}
\hline & & $\begin{array}{c}\text { Sum of } \\
\text { Squares }\end{array}$ & df & Mean Square & $\mathbf{F}$ & Sig. \\
\hline \multirow[t]{3}{*}{$Q 7$} & Between Groups & 14.679 & 1 & 14.679 & 7.901 & .006 \\
\hline & Within Groups & 133.767 & 72 & 1.858 & & \\
\hline & Total & 148.446 & 73 & & & \\
\hline \multirow[t]{3}{*}{$Q 17$} & Between Groups & 12.982 & 1 & 12.982 & 11.059 & .001 \\
\hline & Within Groups & 83.347 & 71 & 1.174 & & \\
\hline & Total & 96.329 & 72 & & & \\
\hline
\end{tabular}

\section{Hypotheses Testing}

From the results of the data analysis, the H1 was rejected: consumers in China of different ages and genders with different purchasing power have different concerns during the on-line transaction process. $\mathrm{H} 2$ was supported in this way: there is a slight difference between $\mathrm{B} 2 \mathrm{C}$ and $\mathrm{C} 2 \mathrm{C}$ in consumers' information/privacy protection while there is no difference between $\mathrm{B} 2 \mathrm{C}$ and $\mathrm{C} 2 \mathrm{C}$ in the on-line payment issue.

\section{CONCLUSIONS}

The opinion that consumers in China of different ages and genders with different purchasing power have the same concerns during the on-line transaction process was disproved, so the ecommerce companies in China should pay more attention to improve the customers' experience of on-line purchasing. However, if the e-commerce companies in China want to make more profits, the most important factor is the strengthening of on-line payment security, because the consumers spending large amounts of money on-line pay a lot of attention to this factor. Additionally, the gender factor will affect consumers' pre-purchasing investigation on the e-commerce companies, which also reminds the e-commerce companies in China to attract different consumers in different ways.

The comparison of consumers' attitudes towards $\mathrm{B} 2 \mathrm{C}$ and $\mathrm{C} 2 \mathrm{C}$ reminds the $\mathrm{C} 2 \mathrm{C}$ companies in China to put more effort into the improvement of their companies' image in public, which could help to attract more consumers.

Finally, one limitation of this study is the student sample because there are many other kinds of econsumers. Additionally, students are not the largest portion of e-consumers in China. However, this is the pilot study for research investigating consumers' attitudes of e-commerce in China. Further work is underway on the data analysis of the "Consumers' attitudes towards Trust," the Part 2 of the research model. In addition, the improvement of the questionnaire design, and the distribution of a larger scaled survey will be included in the future study.

\section{REFERENCES}

1. Chang, L.(2005). Beyond concern: A privacytrust-behavioral intention model of electronic commerce. Information \& Management, 42(2), 289- 304

2. 2.Clark,R.A. (1988). Information technology and dataveillance, Communications of ACM, 31(5), 498-512.

3. 3.Freeman, E,H. (2004).Digital signatures and electronic contracts. Information System Security, 13(2), 8-12.

4. Gritzalis, S. \& Gritzalis, D (2001). A digital seal solution for deploying trust on commercial transactions, Information Management \& Computer Security, 9(2), 71-79.

5. GUV WWW User Survey. (1996).GUV 6th WWW User Survey, Retrieved September 15, 2005 from http://www.gvu.gatech.edu/user_surveys/surve y-10-1996/

6. Huang, W.(2004). Effect of brand name on consumers' risk perceptions of online shopping. Journal of Consumer Behavior. 4(1), 40-50.

7. Kehoe, C. (1997). Surveying the territory. World Wide Web Journal (W3J), 1(3).

8. Kleist, V.R. (2004). A transaction cost model of electronic trust: Transactional return, incentives for network security and optimal risk in the digital economy. Electronic Commerce Research, 4(2), 41-57. 
9. Liu, J \& Hu, L. (2000). Towards an understanding of the behavioral intention to use a web site. International Journal of Information Management, 20(30), 197-208.

10. Loshin, P. (OCTOBER 01, 2001). Transaction Processing. Retrieved September 15, 2005 from the Computer World website: http://www.computerworld.com/databasetopics /data/story/0,10801,64305,00.html

11. Marlin, S.(2005). Consumer worries about online security on the rise. Information Week, (August 18), Available online at http://www.informationweek.com/story/showArt icle.jhtml?articleID=169400081.

12. Mccloskey, D.(2003/2004). Evaluating electronic commerce acceptance with the technology acceptance model. Journal of Computer Information System, 44(2), 49-57.

13. Moores, T.( 2005). Do consumers understand the role of privacy seals in e-commerce? Communications of the ACM, 48(3), 86-91.

14. Richland Community College. (2000). Stats: One-Way Anova. Retrieved September 15, 2005 from http://www.richland.edu/james/lecture/m170/ch1 3-1wy.html

15. Rosenthal, L D. (2000) Consumer protection in the global electronic marketplace: Looking ahead. Federal Trade Commission, Bureau of Consumer Protection. Available online at http://www.ftc. gov/bcp/icpw/lookingahead/appa.pdf

16. Slewe, T. (2004). Who will rob you on the digital highway? Communications of the ACM, 47(5), 56-60.

17. Srinivasan, S.(2004). Role of trust in e-business success. Information Management \& Computer Security, 12(1), 66-72.

18. Warren, S.D \& Brandeis, L.D. (1890). The right to privacy. Harvard Law Review, 4(5), 193-220.

19. Wei, L. (1999). The asymptotically optimal empirical Bayes estimation in one-way ANOVA model. Systems Sci. Math. Sci., 12(1).

20. Yan, W. (2005)._The electronic signatures law: China's first national e-commerce legislation. Intellectual Property \& Technology Law Journal, 17(6), 6. 